\title{
Caring behaviors by nurses in patients' perceptions and experiencing an anxiety during hospitalization
}

\author{
Herwan ${ }^{1}$, Teguh Pribadi2*
}

${ }^{1}$ Rumah Sakit Umum Mayjend H.M. Ryacudu Lampung Utara

2Program Studi IImu Keperawatan Fakultas IImu Kesehatan-Universitas Malahayati

*Corresponding author. E-mail: teguh@malahayati.ac.id

\begin{abstract}
Background: Feeling anxious due to lack of attention from the surroundings can be solved by providing a good caring performance from the health workers. The nursing experts place caring as the core principle of a nurse in performing his work. Caring behavior refers to giving attention to patients, respecting others, and showing empathy so that a nurse should maintain the relationship with the patients by having this the patients can commit and be responsible with them.

Purpose: Knowing Caring behaviors by nurses in patients' perceptions and experiencing an anxiety during hospitalization

Methods: This study was a quantitative study. The design was analytical with cross sectional approach. The population of the study consisted of 262 adult patients in average registered at Ryacudu General Hospital, Kotabumi Lampung. The elder and pediatric inpatients were excluded. The samples were 79 respondents. The sampling technique was accidental sampling.

Results: Based on the statistical analysis, the $p$ value was 0.487 or the $p$ value $>0.05$, there wasn't nursing caring behavior on anxiety level of hospitalized patients.

Conclusion: The health practitioners should improve their nursing quality by following nurse training about therapeutic communication. It is expected that health workers can increase caring so that patient anxiety can be reduced and can improve the quality of health services by providing training to all nursing staff on good and correct therapeutic communication.
\end{abstract}

\section{Keywords: Caring behaviors by nurses; Patients' perceptions; Experiencing an anxiety; Hospitalization}

\section{INTRODUCTION}

Anxiety is an emotional conflict that occurs between two personality elements namely id and superego. Id symbolizes primitive instinctual impulses and impulses, the superego reflects one's conscience, while the ego or I is described as a mediator of the demands of the id and superego. Anxiety serves to warn the ego about a danger that needs to be overcome. Anxiety occurs from fear and interpersonal rejection, this is combined with trauma during the growth period such as loss or separation that leaves a person helpless. Individuals who have low self-esteem are usually very easy to experience severe anxiety (Nursalam, 2016).

The results of a previous survey there were 50 of 700 patients who were canceled for surgery, due to psychological factors namely anxiety. The incidence of perioperative anxiety has been reported between $11 \%-80 \%$ among adult patients. Anxiety can cause physical and psychological changes that ultimately activate the sympathetic autonomic nerves, thereby increasing heart rate, blood pressure,frequency breathing, and generally reducing energy levels in the patient, and ultimately can harm the patient itself. Physical and emotional stress increases body temperature through hormonal and nerve stimulation (Stuart, 2006).

The prevalence of Indonesian population experiencing mental emotional disorders nationally such as anxiety and depression disorders by $6 \%$ (Ministry of Health of the Republic of Indonesia, 2013). Anxiety becomes the biggest mental disorder, an estimated $20 \%$ of the world's population suffers from anxiety (Hidayati, Widodo, 
Caring behaviors by nurses in patients' perceptions and experiencing an anxiety during hospitalization

\& Kartinah, 2013). There are $33 \%$ of respondents think that anxiety can be life threatening and almost half of the respondents $49.5 \%$ stated that it is very dangerous if anxiety is not handled properly (Frazier, Moser, Daley, McKinley, Riegel, \& Garvin, 2003; Hidayati, Widodo, \& Kartinah, 2013).

When an anxiety does not get the attention of an environment, then that anxiety can be overcome by caring behavior by health workers. Nursing experts place caring as a very basic center of attention in nursing practice, because many researchers on caring reveal that unmet patient expectations are rarely related to competence, but more often because patients feel nurses are insensitive to their needs or lack respect for their point of view in short "do not care" (Nursalam, 2016).

The nursing management process in the application field is parallel to the nursing process, so the existence of nursing management is intended to facilitate the nursing action process (Kuntoro, 2010). Increasing and stabilizing the role of nurses lately has become a demand of society, both in services health in general and nursing in particular. $90 \%$ of services in hospitals are provided by nurses, therefore nurses have a very big role in determining the quality of hospital services. A nurse must always develop attitudes, behaviors and knowledge in conducting assessments, planning, implementation and evaluation in practice. One of the attitudes and behaviors that must be developed by nurses is caring behavior (Suarli, \& Bahtiar, 2012). Behavior caring is a concern to others, respect for others, and empathy for others, so that the nurses were able to maintain valuable relationships with patients so that they feel a commitment and responsibility towards himself (Bastable, 2002; Asmadi, 2008). The nurse is part of a team that is in the forefront to serve because it treats patients for 24 hours. Nursing services as professional services are humanistic services that are carried out based on knowledge and tips oriented to the needs of patients, both individually, families, groups and communities based on the ethics of the nursing profession (Morrison, \& Burnard, 2009).
Nurse caring behavior is a nurse's performance that is influenced by the nurse's demographics such as age, sex, education, marital status, family background and years of service (Hidayati, Widodo, \& Kartinah, 2013). Caring behavior can be in the form of helping, helping, caring attitude towards patients, calming, providing protection against loss, maintaining the dignity of patients and serving patients who need services, especially meeting basic needs. Caring given to patients can provide a sense of security, comfort, fulfillment of physical, emotional and spiritual needs that can reduce anxiety thereby speeding up the healing process. While the impact of attitudes non-caring nurses on the quality of nursing services for patients are feelings of shame, fear, despair, helplessness, alienation, vulnerability, bad memories, loss of self-control and slowing down the healing process (Morrison, \& Burnard, 2009).

Previous studies found the results of testing the relationship between behavior caring nurse to patient anxiety obtained $p$-value $=0,000$, thus at a significance level of $5 \%$ the $p$-value is smaller than the significance level or $0,000<0.05$ then it was decided that $\mathrm{HO}$ was rejected and accepted $\mathrm{Ha}$, it was concluded that there was a significant relationship between behavior caring nurses towards patient anxiety (Hidayati, Widodo, \& Kartinah, 2013).

Based on medical record at Ryacudu General Hospital, patients who have been hospitalized by type of service: (internal medicine: in 2015 there were 395 and in 2016 there were 517), (operating ward: in 2015 there were 93 and in 2016 there were 120), (children disease ward: in 2015 there were 89 and in 2016 there were 103), (obstetrics and womb space: in 2015 there were 237 and in 2016 there were 290) and (VIP ward: in 2015 there were 85 and in 2016 there were 132), so it was known the total number of visits in 2015 totaled 899 and in 2016 amounted to 1,162.

Based ondata pre-survey that researchers conducted with interviews, 10 patients who were hospitalized operating in the ward with diagnoses different medical. 3 patients $(30 \%)$ revealed that some nurses behaved politely and friendly, were willing to provide the needs of patients, provide

\section{Herwan', Teguh Pribadi* ${ }^{2 *}$}

'Rumah Sakit Umum Mayjend H.M. Ryacudu Lampung Utara

${ }^{2}$ Program Studi llmu Keperawatan Fakultas Ilmu Kesehatan-Universitas Malahayati

${ }^{*}$ Corresponding author. E-mail: teguh@malahayati.ac.id 
Caring behaviors by nurses in patients' perceptions and experiencing an anxiety during hospitalization

answers to patient questions, so that patients felt calm and comfortable during their stay. However, 7 patients $(70 \%)$ revealed that their nurses never asked the patient's condition, answered questions in a loud tone, lacked behavior polite and did not respect the patient's rights. Based on observational data on 10 patients, it is known that 7 patients (70\%) look worried and 3 patients (30\%) appear calm and relaxed.

\section{RESEARCH METHODS}

Quantitative research type, analytical research design with cross sectional approach. The study passed the ethical eligibility of the Malahayati University Health Research Ethics Commission (MHREC) and was carried out in the internal medicine and surgery ward at Ryacudu General Hospital Kotabumi, North Lampung on June 2019. The population of all adult inpatients except children and the elderly with an average the average visit reached 262 patients and a sample of 79 respondents. The sampling technique used was accidental sampling. In conducting data collection, measuring instruments that researchers use questionnaire sheets containing caring behavior and SAS / SRAS sheets to determine the level of patient anxiety. To find out the caring behavior variable, researchers used a questionnaire that had been tested for validity, namely adoption from previous studies, where there were 19 questions with answer options very often (4), often (3), sometimes (2) and never (1), so the respondent will get the highest score of 76 , if the respondent's score $>$ mean then the behavior is categorized as good, whereas if the respondent's score is $\leq$ mean, then the respondent's caring behavior category is not good (Sirait, 2013). To determine the level of patient anxiety, researchers used instruments SelfRating Anxiety Scale (SAS / SRAS) is an assessment of anxiety in adult patients developed based on anxiety symptoms in the Diagnostic and Statistical Manual of Mental Disorders (DSM-II). There are 20 questions, each of which is rated 1-4 (1: never, 2: sometimes, 3: some time, and 4: almost every time). There are 15 questions towards increasing anxiety and 5 questions towards decreasing anxiety, if the score $\leq$ means the category is not anxious, and if the score $>$ mean is the anxiety category (Zung, 1971; Kamalah, Ahsan, \& Kristianto, 2016).

Data collection techniques are based on primary data, namely data taken from the results of filling out the questionnaire given to respondents, after the data is obtained then data analysis will be performed with a computer program. Before the researcher distributes the questionnaire, the patient is expected to be able to fill out the questionnaire provided. Bivariate analysis using chi-square test with p-value $<0.05$.

\footnotetext{
Herwan', Teguh Pribadi ${ }^{2 *}$

'Rumah Sakit Umum Mayjend H.M. Ryacudu Lampung Utara

${ }^{2}$ Program Studi llmu Keperawatan Fakultas Ilmu Kesehatan-Universitas Malahayati

${ }^{*}$ Corresponding author. E-mail: teguh@malahayati.ac.id
} 


\section{RESEARCH RESULTS}

Table 1. Frequency Distribution Characteristics of Respondents

$\mathrm{N}=79$

\begin{tabular}{lcc}
\hline Characteristics of Respondents & $\begin{array}{c}\text { Frequency } \\
\text { (f) }\end{array}$ & $\begin{array}{c}\text { Percentage } \\
(\%)\end{array}$ \\
\hline Age (Years) & 46 & 58,2 \\
25-32 years & 33 & 41,8 \\
$33-43$ years & & \\
Gender & & \\
Male & 37 & 46,8 \\
Female & 42 & 53,2 \\
& & \\
Education Levels & & \\
Primary school & 20 & 25,3 \\
Secondary school & 22 & 27,8 \\
High school & 23 & 29,1 \\
Diploma & 13 & 16,5 \\
University & 1 & 1,3 \\
& & \\
Job Title & & \\
Labor & 35 & 44,3 \\
Government Employees & 3 & 3,8 \\
Private Employees & 7 & 8,9 \\
Entrepreneur & 34 & 43,0 \\
\hline
\end{tabular}

Based on table 1, it is known that the majority of respondents aged 25-32 years, amounting to $46(58.2 \%)$, female of $42(53.2 \%)$, high school education level of $23(29.1 \%)$, and as laborers of $35(44.3 \%)$

Table 2. Frequency Distribution of Caring Behaviors by Nurses In Patients' Perceptions

\begin{tabular}{lcc} 
Caring behaviors by nurses & $\begin{array}{c}\text { Frequency } \\
(\mathbf{f})\end{array}$ & $\begin{array}{c}\mathbf{N}=79 \\
\text { Percentage } \\
(\%)\end{array}$ \\
\hline Good & 47 & 59.5 \\
Poor & 32 & 40.5 \\
Total & 79 & 100,0 \\
\hline
\end{tabular}

Based on table 2. Shown that caring behaviors by nurses in patients' perceptions in a good category of 47 $(59.5 \%)$ 
Table 3. Patients Has Experienced an Anxiety During Hospitalization

\begin{tabular}{lcc} 
& & $\mathbf{N}=\mathbf{7 9}$ \\
\hline Patient's experience an anxiety & $\begin{array}{c}\text { Frequency } \\
\text { (f) }\end{array}$ & $\begin{array}{c}\text { Percentage } \\
(\%)\end{array}$ \\
\hline Ever & 42 & 53,2 \\
Never & 37 & 46,8 \\
Total & $\mathbf{7 9}$ & $\mathbf{1 0 0 , 0}$ \\
\hline
\end{tabular}

Based on table 3. Shown that Patients Has Experienced an Anxiety During Hospitalization of 42 (53.2\%)

Table 4. Caring Behaviors by Nurses in Patients' Perceptions and Experiencing an Anxiety During Hospitalization

\begin{tabular}{|c|c|c|c|c|c|c|c|c|}
\hline \multirow{4}{*}{$\begin{array}{l}\text { Caring } \\
\text { behaviors by } \\
\text { nurses }\end{array}$} & & & & & & & & $\mathrm{N}=79$ \\
\hline & \multicolumn{4}{|c|}{$\begin{array}{l}\text { Patient's experience } \\
\text { an Anxiety }\end{array}$} & \multirow{2}{*}{\multicolumn{2}{|c|}{ Total }} & \multirow{3}{*}{ p-value } & \multirow{3}{*}{ OR (CI 95\%) } \\
\hline & \multicolumn{2}{|c|}{ Ever } & \multicolumn{2}{|c|}{ Never } & & & & \\
\hline & $\mathrm{n}$ & $\mathrm{n}$ & $\mathrm{n}$ & $\%$ & $\mathbf{N}$ & $\%$ & & \\
\hline Good & 27 & 20 & 20 & 57,4 & 47 & 100,0 & \multirow{3}{*}{0,487} & \multirow{3}{*}{$\begin{array}{l}1,530 \\
(0,620-3,777\end{array}$} \\
\hline Poor & 15 & 17 & 17 & 46,9 & 32 & 100,0 & & \\
\hline Total & 42 & 37 & 37 & 53,2 & 79 & 100,0 & & \\
\hline
\end{tabular}

Based on table 4. it is known that there are 47 nurses who have a good caring behavior, where 20 patients (42.6\%) never experience anxiety , and 27 patients $(57.4 \%)$ ever experience an anxiety, while there were 32 nurses who had poor caring behavior, where 17 patients (53.1\%) never experience an anxiety and 15 patients (46.9\%) experienced an anxiety.Based on the results of statistical tests, $p$-value 0.487 or $p$-value $>$ a $(0.05)$ means that there is no relationship between caring behaviors by nurses in patients' perceptions and experiencing an anxiety during hospitalization with an $\mathrm{OR}$ value of 1.530 , which means that poor caring behaviors by nurses have a 1.530 chance greater times to cause an anxiety to the patient During Hospitalization.

\section{DISCUSSION}

Based on the results of the study, it is known that some nurses have good caring behavior 47 $(59.5 \%)$. Caring as a way for nurses to maintain a valuable relationship with patients so that they feel commitment and responsibility towards themselves. Caring is also an interpersonal characteristic that is not genetically inherited, but can be learned through education as a professional culture (Watson, 2007; Priyoto, 2015). To perpetuate caring in practice, it is necessary to increase the focus of education so that a commitment to maintain appears caring as a central value (Woodward, 1997; Pratiwi, 2017). The results of previous studies concluded that there was a significant relationship between nurses caring behavior with patient satisfaction in the inpatient ward with a $p$ value of 0.001 (Darmawan, 2016). According to researchers caring behavior is very important for the level of quality of health services in hospitals. However, researchers found the phenomenon that caring behavior for nurses is still poor, this is due to the lack of a positive attitude towards nurses about the services provided, as well as the lack of support from the hospital to hold health seminars on how to provide quality health services, and based on assessment of the questionnaire which has the highest score on question number 15 regarding the nurses's concern/interest in the patient's problem.

\section{Herwan', Teguh Pribadi* ${ }^{2 *}$}

'Rumah Sakit Umum Mayjend H.M. Ryacudu Lampung Utara

${ }^{2}$ Program Studi Ilmu Keperawatan Fakultas Ilmu Kesehatan-Universitas Malahayati

${ }^{*}$ Corresponding author. E-mail: teguh@malahayati.ac.id 
Caring behaviors by nurses in patients' perceptions and experiencing an anxiety during hospitalization

Based on the results, knowing that the majority of in patients experienced anxiety totaling 42 $(53.2 \%)$. Anxiety is closely related to feelings of uncertainty and helplessness. This emotional state has no specific object, conditions are experienced subjectively and communicated in interpersonal relationships. Anxiety is different from fear, which is an intellectual assessment of something dangerous. The capacity to be anxious is needed to survive during of the life. The anxiety response range describes a degree of anxiety experienced by an individual (Hawari, 2013).

Previous studies have shown by behavior in a poor caring and patients experiencing anxiety moderate of $8(50 \%)$, severe anxiety of $6(37 \%)$, and mild anxiety of 2 (13\%). Furthermore, by a moderate caring and patients experiencing a moderate anxiety of $27(43 \%)$, mild anxiety of 24 $(38 \%)$, and severe anxiety of $12(19 \%)$. Whereas by a good nurses caring and patients experiencing of $13(100 \%)$ had mild anxiety levels. (Hidayati, Widodo, \& Kartinah, 2013). Based on the results of research conducted by researchers, the phenomenon that researchers found that most patients experience anxiety, many factors affect patient anxiety, one of which is the process of care in the hospital including the behavior of nurses who uncaring and lack of attention will affect patients less confident and will experience worry.

Based on the results of the study, it is known that there are 47 nurses who have good caring behavior, where 20 patients (42.6\%) never experience an anxiety, and 27 patients $(57.4 \%)$ experienced an anxiety, while there were 32 nurses who have poor caring behavior, where 17 patients $(53.1 \%)$ never experience an anxiety and 15 patients $(46.9 \%)$ experienced an anxiety. Based on the results of statistical tests, p-value 0.487 or $p$-value $>$ a $(0.05)$ means that there is no relationship between nurses caring behavior with patient anxiety with an $\mathrm{OR}$ value of 1.530 , which means that respondents who have poor caring behavior have a 1.530 chance times greater to cause anxiety. In line with the theory which states that if anxiety does not get attention by an environment, then that anxiety can be overcome by caring behavior by health workers. Nursing experts place caring as a very basic center of attention in nursing practice, because many researchers on caring reveal that unmet patient expectations are rarely related to competence, but more often because patients feel nurses are in sensitive to their needs or lack respect for their point of view in short "uncaring" (Nursalam, 2016).

The results of this study are in line with previous studies showing that respondents stated that nurses' behavior caring were 24 respondents $(60.0 \%)$, and respondents who expressed satisfaction were $22(55.0 \%)$ respondents. There is a significant relationship between nurses caring behavior with family satisfaction of mental patients with ( $p$-value 0.005). Suggestions for nurses to improve behavioral abilities caring by periodic evaluations related to behavior caring (Sera, Triyoso, \& Furqoni, 2014). In the results of research conducted by researchers, there were 12 patients who experienced severe anxiety, but 6 patients $(18.8 \%)$ got good caring behavior this is due to lack of patient knowledge about treatment procedures or treatment of disease, and also there were 38 patients who did not experience anxiety, but 29 patients $(61.7 \%)$ get poor caring behavior, this is due to family support and high motivation from personal patients.

\section{CONCLUSION}

Knowing that the majority of respondents aged 33-43 years, amounting to 43 respondents $(54.5 \%)$, female sex numbered 42 respondents $(53.2 \%)$, the last high school education was 23 respondents $(29.1 \%)$, and had employment as laborers amounted to 35 respondents (44.3\%). It is known that some nurses have good caring behavior totaling 47 respondents $(59.5 \%)$, most inpatients experience anxiety which amounts to 42 respondents $(53.2 \%)$. Based on the results of statistical tests, $p$-value 0.487 or $p$-value $<0.05$, which means there is no relationship between nurses caring behavior with patient anxiety.

\section{RECOMMENDATION}

The health workers can improve the quality of health services by providing facilities and infrastructure regarding the importance of caring

\section{Herwan', Teguh Pribadi* ${ }^{2 *}$}

\footnotetext{
'Rumah Sakit Umum Mayjend H.M. Ryacudu Lampung Utara

${ }^{2}$ Program Studi llmu Keperawatan Fakultas Ilmu Kesehatan-Universitas Malahayati

${ }^{*}$ Corresponding author. E-mail: teguh@malahayati.ac.id
} 
behavior through the basic service motto " 5 codes" (smiles, greetings, genteel, polite and ethical), as well as providing training for all nursing staff on good therapeutic communication.

\section{REFERENCES}

Asmadi, N. (2008). Konsep dasar keperawatan. Jakarta: EGC.

Bastable, S. B. (2002). Perawat sebagai pendidik. Jakarta: EGC.

Darmawan, A. K. N. (2016). Hubungan Perilaku Caring Perawat Terhadap Tingkat Kepuasan Pasien Rawat Inap Di RSUD Klungkung. Jurnal Dunia Kesehatan, 5(1).

Frazier, S. K., Moser, D. K., Daley, L. K., McKinley, S., Riegel, B., \& Garvin, B. J. (2003). Critical care nurses' beliefs about and reported management of anxiety. American Journal of Critical Care, 12(1), 19-27.

Hawari, D. (2013). Manajemen Stres Cemas dan Depresi: Jakarta Fakultas Kedokteran Universitas Indonesia.

Hidayati, N., Widodo, A., \& Kartinah, A. K. (2013). Hubungan perilaku caring perawat dengan tingkat kecemasan pasien rawat inap di rumah sakit PKU Muhammadiyah Surakarta (Doctoral dissertation, Universitas Muhammadiyah Surakarta).

Kamalah, A. D., Ahsan, A., \& Kristianto, H. (2016). Efektivitas Psikoedukasi Keluarga Pada Caregiver Pasien Ulkus Diabetes Melitus Dalam Menurunkan Tingkat Ansietas. Jurnal IImu Keperawatan, 4(2), 85-98.

Kementerian Kesehatan Republik Indonesia. (2013). Riset kesehatan dasar (Riskesdas) 2013. Jakarta: Badan Penelitian dan Pengembangan Kesehatan Kementerian Kesehatan RI.

Kuntoro, A. (2010). Buku ajar manajemen keperawatan. Yogyakarta: Nuha Medika.
Morrison, P., \& Burnard, P. (2009). Caring and Communicating Hubungan Interpersonal dalam Keperawatan. EGC.

Nursalam, N. (2016). Manajemen keperawatan: Aplikasi dalam praktek keperawatan profesional. Jakarta: Salemba Medika.

Pratiwi, L. (2017). Hubungan tingkat pengetahuan perawat tentang caring terhadap pencapaian tahapan hubungan interpersonal perawat-pasien di ruang rawat inap RS DKT Jember.

Priyoto. (2015). Komunikasi dan Sikap Empati dalam Keperawatan. Yogyakarta: Graha IImu.

Sera, T. S., Triyoso, T., \& Furqoni, P. D. (2014). Hubungan Perilaku Caring Perawat Dengan Kepuasan Keluarga Pasien Jiwa Di IRJ RSJD Provinsi Lampung Tahun 2014. Holistik Jurnal Kesehatan, 8(4).

Sirait, R. (2013). Pengaruh Kepribadian Dengan Perilaku Caring Perawat Di Ruang Rawat Inap Rumah Sakit Umum dr. Pirngadi Medan.

Stuart, G. W. 2006. Buku Saku Keperawatan Jiwa. Jakarta: EGC.

Suarli, S., \& Bahtiar, Y. (2012). Manajemen keperawatan dengan pendekatan praktis. Jakarta: Erlangga.

Watson, J. (2007). Watson s theory of human caring and subjective living experiences: carative factors/caritas processes as a disciplinary guide to the professional nursing practice. Texto \& Contexto-Enfermagem, 16(1), 129-135.

Woodward, V. M. (1997). Professional caring: a contradiction in terms?. Journal of Advanced Nursing, 26(5), 999-1004.

Zung, W. W. (1971). A rating instrument for anxiety disorders. Psychosomatics: Journal of Consultation and Liaison Psychiatry.

\section{Herwan', Teguh Pribadi* ${ }^{2 *}$}

'Rumah Sakit Umum Mayjend H.M. Ryacudu Lampung Utara

${ }^{2}$ Program Studi llmu Keperawatan Fakultas Ilmu Kesehatan-Universitas Malahayati

${ }^{*}$ Corresponding author. E-mail: teguh@malahayati.ac.id 